\title{
ERRATUM
}

\section{Increasing drought under global warming in observations and models}

Aiguo Dai

Nature Clim. Change 3, 52-58 (2013); published online 5 August 2012; corrected after print 22nd January 2013.

In the version of this Letter originally published, in the sentence beginning "As SSTs have large influences on land precipitation...", the latitude range of sc_PDSI_pm included in the maximum covariance analysis should have read $60^{\circ} \mathrm{S}-75^{\circ} \mathrm{N}$. This error has now been corrected in the HTML and PDF versions (note that the 'corrected after print' date in these online versions differs from that given in print). 